\title{
Stability of bacterial and viral community compositions in Danish coastal waters as depicted by DNA fingerprinting techniques
}

\author{
Lasse Riemann*, Mathias Middelboe \\ Marine Biological Laboratory, University of Copenhagen, Strandpromenaden 5, 3000 Helsingør, Denmark
}

\begin{abstract}
Variations in bacterial and viral community compositions were examined over spatial scales ranging from centimeters to kilometers and over temporal scales of days to months in Danish coastal environments by means of denaturing gradient gel electrophoresis (DGGE) and pulsed field gel electrophoresis (PFGE), respectively. Despite several-fold differences in bacterial activity and chlorophyll $a$, we found only a few differences in microbial community composition among samples from $30 \mathrm{~cm}$ intervals in a $3 \mathrm{~m}$ vertical profile across a narrow pycnocline during a subsurface coccolithophorid bloom in the southern Kattegat. Likewise, only a few changes in community composition were observed during a 2 mo spring bloom period in the eutrophic Roskilde Fjord. However, more pronounced differences were observed among samples from 5 stations on a transect crossing the Skagerrak-Kattegat front where 2 water masses with different physico-chemical properties meet. The 2 water masses harbored distinct bacterial and viral communities, and a gradual mixing of the microbial communities was observed across the front. Our study indicates stability of microbial community compositions in Danish coastal waters and suggests that changes in microbial abundance and activity were not associated with successions in bacterial and viral communities discernible by the applied DGGE and PFGE protocols.
\end{abstract}

KEY WORDS: Bacteria · Virus · Fingerprinting $\cdot$ Denaturing gradient gel electrophoresis $\cdot$ DGGE · Pulsed field gel electrophoresis · PFGE

\section{INTRODUCTION}

The last decade of microbial molecular ecology has resulted in a growing awareness of the tremendous bacterial species diversity found in the world's oceans (Giovannoni \& Rappé 2000). Bacterial populations have different metabolic and enzymatic properties (Martinez et al. 1996, Garrity 2001), and the composition and dynamics of bacterial populations, therefore, affect the overall cycling of organic matter. Thus, in order to understand and ultimately predict bacterial influence on biogeochemical processes in the oceans,

*Present address: Freshwater Biological Laboratory, University of Copenhagen, 51 Helsingørsgade, 3400 Hillerød, Denmark. E-mail: lriemann@vip.cybercity.dk it is necessary to focus on the coupling between genetic and functional characteristics of the microbial community and more general measurements of bacteria-mediated processes, i.e. to ask not only 'what is out there?' but also 'what are they doing and at what rates?' At present, there are 2 obvious impediments to a better understanding of effects of bacterial population dynamics on processing of organic matter in the ocean: (1) lack of knowledge about the correspondence between phenotype and genotype of the many abundant but uncultivated marine bacteria and (2) lack of knowledge of the temporal and spatial scales at which bacterial populations vary.

So far, most studies of bacterial community dynamics have focused either on large scales in space (Ferrari \& Hollibaugh 1999, Schauer et al. 2000) or time (Murray 
et al. 1998, Riemann et al. 1999) or on short-term changes (within days) under natural or experimental conditions (Fandino et al. 2001, Schäfer et al. 2001). A comparison of recent studies of bacterial community dynamics in pelagic marine waters showed large variations between the community changes observed in the different studies. For instance, denaturing gradient gel electrophoresis (DGGE) patterns from samples obtained $1500 \mathrm{~km}$ apart in the Arabian Sea were found to be almost identical (Riemann et al. 1999), and only minimal differences in community compositions were observed at stations a few miles apart near Anvers Island, Antarctica (Murray et al. 1998). However, along the Catalan Coast (Spain), clear differences were observed (Schauer et al. 2000). These studies indicate that hydrography and to a smaller extent productivity might determine the degree of bacterial community differences when comparing spatially separated locations. However, short-term studies show that successions within bacterial communities are a common consequence of large alterations in the organic matter field (Pinhassi et al. 1999, Van Hannen et al. 1999, Riemann et al. 2000, Fandino et al. 2001, Schäfer et al. 2001).

Theoretically, changes in bacterial community composition in time and space may be a result of changing substrate conditions, changing mortality caused by viral lysis or protozoan grazing, and changing physicochemical conditions that favor or inhibit specific subpopulations. It is therefore reasonable to expect that successions in bacterial community composition are related to changes in environmental factors (e.g. chlorophyll concentration, primary production, viral and protozoan abundance and composition, salinity, temperature) that affect bacterial abundance and activity. Recent studies of viral population dynamics (Castberg et al. 2001, Larsen 2001) revealed dynamic bacterial and viral communities during phytoplankton blooms in seawater enclosures, indicating a close linkage between algal, bacterial and viral populations.

Large variations in microbial activity are commonly observed over seasonal scales (e.g. Nielsen \& Richardson 1989, Ducklow et al. 1993) and over large spatial gradients, e.g. from coastal areas to the open ocean (Karner et al. 1992, Rath et al. 1993). However, pronounced variations in microbial abundances and activities over small scales in space or time also seem to be a common phenomenon in marine plankton, e.g. variations in bacterial abundance within millimeters and centimeters (Mitchell \& Fuhrman 1989, Seymour et al. 2000), changes in viral abundance within minutes (Bratbak et al. 1996) or diurnal variations in ectoenzymatic activities (Karner \& Rassoulzadegan 1995), bacterial production (Riemann \& Søndergaard 1984) and amino acid assimilation (Jørgensen et al. 1983). Thus, if it is assumed that changes in growth conditions and in bulk microbial activity are reflected in successions within the given microbial community, then microbial community structure is likely to change on a variety of temporal and spatial scales.

The goal of this study was to test the hypothesis that variations in environmental factors within a given water mass or between different water masses are reflected in temporal and spatial variability of bacterial and viral community structure. Variations in community composition of bacterio- and virioplankton over spatial scales ranging from centimeters to kilometers in 2 coastal environments and over temporal scales of days to months in a eutrophic fjord were analyzed by DGGE and pulsed field gel electrophoresis (PFGE), respectively. The analyses of microbial community composition were combined with measurements of biological and physico-chemical parameters.

\section{MATERIALS AND METHODS}

Sampling locations and strategies. Samples were obtained from 3 different coastal locations in Denmark (Fig. 1).

(1) At the Skagerrak-Kattegat plume front (Stns 1 to 5) oceanic water (>33\%) from the north meets the low-salinity water (15 to $25 \%$ ) from the south, and the front is normally characterized by a high phytoplank-

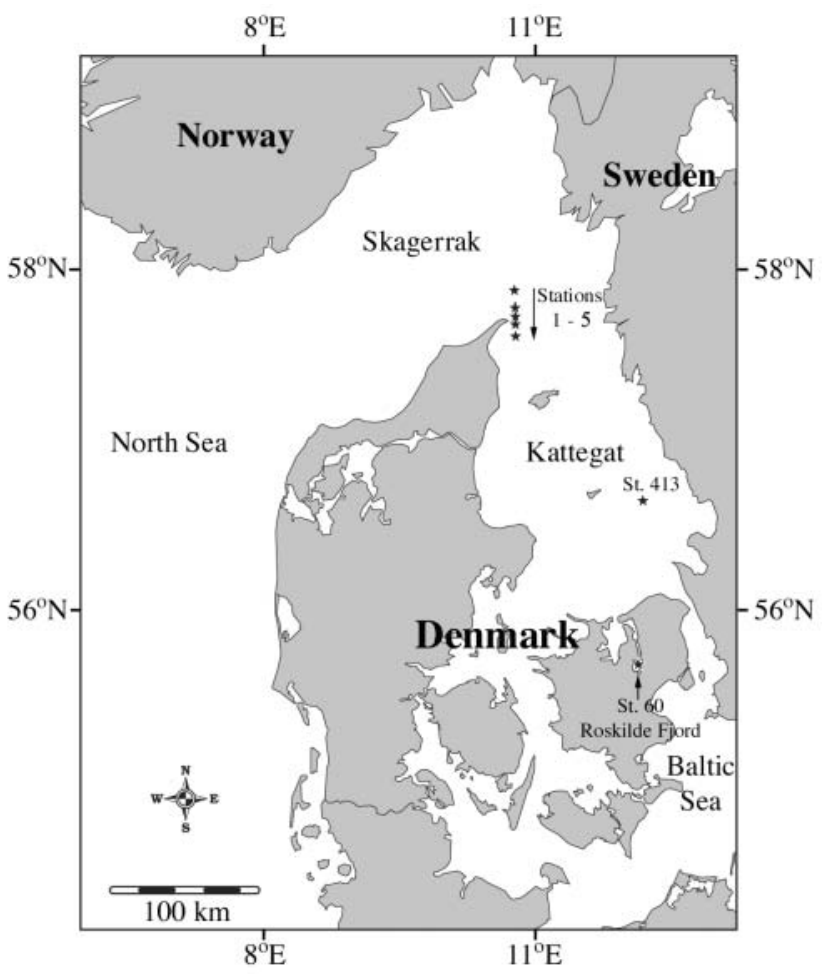

Fig. 1. Map of the sampling locations 
ton biomass relative to the surrounding waters (Heilmann et al. 1994). In the productive season (from April to September/October), the position of this front is generally predictable (Heilmann et al. 1994). Samples were obtained on May 2, 2000, using a 101 Niskin water sampler at 3 to 5 and 15 to $20 \mathrm{~m}$ depths at 5 stations in a transect crossing the front in order to examine microbial dynamics in and around the zone where 2 water masses with different physico-chemical properties meet (Fig. 2). Profiles of salinity, temperature and fluorescence were recorded at each station before sampling. Samples for bacterial production measurements from above the pycnocline were incubated in flowing surface water, while samples from below the pycnocline were incubated at $4{ }^{\circ} \mathrm{C}$.

(2) Kattegat may be viewed as a large estuary with freshwater input from the Baltic Sea and saltwater input from the Skagerrak (North Sea). The sampling area in Kattegat is characterized by a pronounced pycnocline, which is often accompanied by narrow subsurface layers of phytoplankton in the productive season (Nielsen et al. 1990, Bjørnsen \& Nielsen 1991). Samples were taken for investigating the distribution of microbial composition, activity and abundance around the pycnocline on May 3, 2000, at Stn 413 $\left(56^{\circ} 40.00^{\prime} \mathrm{N}, 12^{\circ} 07.00^{\prime} \mathrm{E}\right)$ in the southern Kattegat by using a gradient multi-sampler, which takes 20 duplicate samples simultaneously at $15 \mathrm{~cm}$ depth intervals. Initially, depth profiles of salinity, temperature and fluorescence were recorded with a conductivity,

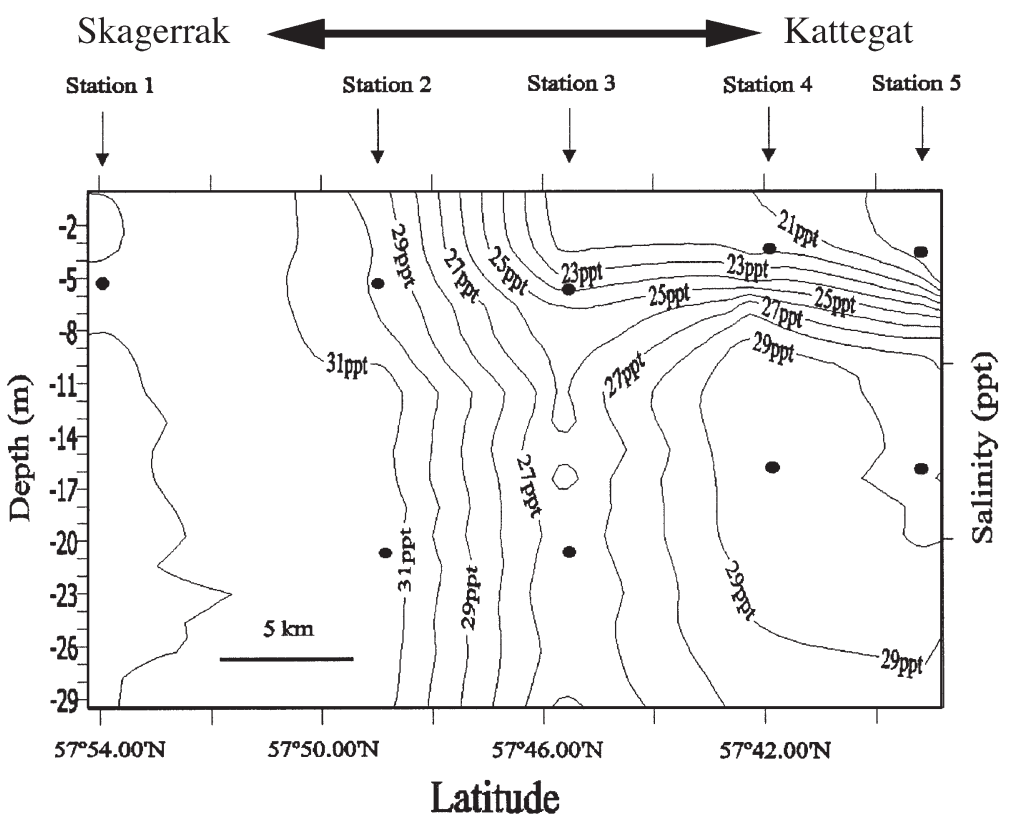

Fig. 2. An isoplet diagram of salinity across the Skagerrak-Kattegat plume front showing the stations and sampling depths (black dots). The diagram is based on a conductivity, temperature and depth (CTD) profile from each station temperature and depth profiler (CTD; YSI Water Quality Systems 6000) attached to a fluorometer. On deck, the contents of 2 duplicate syringes were pooled in order to obtain enough water sample. From the upper and lower end of the sampler, 3 duplicate samples were pooled. Processing of samples was initiated immediately. Samples for bacterial production measurements were incubated in flowing surface water to approximate in situ temperatures.

(3) Roskilde Fjord is a eutrophic, relatively shallow fjord in North Zealand. Samples were obtained at 13 time points from February 29 to April 25, 2000, in order to study microbial dynamics associated with the spring phytoplankton bloom. Samples were collected from $2 \mathrm{~m}$ depth at $\operatorname{Stn} 60\left(55^{\circ} 42.78^{\prime} \mathrm{N}, 12^{\circ} 04.00^{\prime} \mathrm{E}\right)$ in the center of the central basin of the fjord. The total depth at the station is $5 \mathrm{~m}$. Aliquots for microbial counts were fixed immediately after sampling and rate measurement initiated thereafter. Samples and incubations were kept roughly at in situ temperature using an insulated bag. Within $2 \mathrm{~h}$ of sampling, samples for chlorophyll a (chl a), DNA extraction and viral concentrates were processed, then immediately frozen or fixed for later analysis.

DNA filtration and extraction. DNA from Roskilde Fjord was obtained by filtering 2 to $3 \mathrm{l}$ of water through $0.22 \mu \mathrm{m}$ Sterivex capsule filters (Millipore) via peristaltic pump. Filters were frozen at $-80^{\circ} \mathrm{C}$ until extraction. DNA was extracted from the filters by the lysozyme-sodium dodecyl sulfate-proteinase K-RNase protocol provided by Somerville et al. (1989) as modified by Riemann et al. (2000). Extracted and ethanol-precipitated DNA was resuspended in $100 \mu \mathrm{l}$ TE buffer (10 mM Tris, 1 mM EDTA, pH 8.0).

DNA from Kattegat/Skagerrak was obtained by filtering 300 to $500 \mathrm{ml}$ sample through $47 \mathrm{~mm}$ diameter, $0.2 \mu \mathrm{m}$ membrane filters (Supor-200, GelmanSciences). Filters were frozen immediately at $-20^{\circ} \mathrm{C}$ until extraction. For nucleic acid extraction, half of each $0.2 \mu \mathrm{m}$ filter was cut into pieces and vortexed in $500 \mu \mathrm{TE}$ buffer. Cells were lysed by a freeze-thaw-boil protocol: $5 \mathrm{~min},-80^{\circ} \mathrm{C} ; 10 \mathrm{~min}, 20^{\circ} \mathrm{C} ; 10$ $\min , 102^{\circ} \mathrm{C}$. Cell debris and filter pieces were removed by centrifugation $(15000 \times$ $g, 10 \mathrm{~min})$, and DNA in the supernatant was precipitated with $1 / 4 \mathrm{vol} 10.5 \mathrm{M}$ sodium acetate and 3 vol $96 \%$ ethanol, washed with $70 \%$ ethanol and resuspended in $50 \mu \mathrm{l}$ TE buffer . DNA was quantified fluorometrically (PicoGreen, Molecular Probes). 
Polymerase chain reaction (PCR) amplification and DGGE. Bacterial 16S rDNA was amplified using a bacterial primer complementary to positions 341 to 358 with a 40 base pair (bp) GC-clamp (underlined) (5'CGCCCGCCGCGCGCGGCGGGCGGGGCGGGGG CACGGGGGGCCTACGGGA GGCAGCAG-3'; Muyzer et al. 1993) and a universal primer complementary to positions 907 to 927 (CCGTCAATTCA/ CTTTGAGTTT; Muyzer et al. 1998). PCR reactions $(50 \mu l)$ contained 1× PCR buffer (Perkin Elmer), $2.25 \mathrm{mM}$ $\mathrm{MgCl}_{2}, 0.8 \mathrm{mM}$ deoxynucleotide triphosphates, $0.5 \mu \mathrm{M}$ of each primer, 0.25 to $1 \mathrm{ng}$ of template DNA and Amplitaq Gold polymerase (Perkin Elmer). One unit of polymerase per reaction was used for the Kattegat samples while 1.5 units of polymerase was necessary for the Roskilde Fjord samples in order to obtain sufficient PCR products, most likely due to compounds in the DNA extract inhibiting polymerase activity. Initial denaturation was at $95^{\circ} \mathrm{C}$ for 6 min followed by thermal cycling programs as follows: denaturation for $30 \mathrm{~s}$ at $94^{\circ} \mathrm{C}$; primer annealing for $30 \mathrm{~s}$ at an initial $63^{\circ} \mathrm{C}$, decreasing $1{ }^{\circ} \mathrm{C}$ every 2 cycles to a final of $53^{\circ} \mathrm{C}_{i}$ and primer extension for $90 \mathrm{~s}$ at $72^{\circ} \mathrm{C}$. Ten cycles were run at $53^{\circ} \mathrm{C}$ for a total of 30 cycles followed by a final $7 \mathrm{~min}$ incubation at $72^{\circ} \mathrm{C}$. Negative controls, in which the template was replaced by an equivalent volume of sterile water, were included in each batch of PCR reactions. The quality and size of PCR products were verified by agarose gel electrophoresis.

Duplicate $50 \mu \mathrm{l}$ PCR reactions were pooled, purified using the High Pure PCR Product Purification Kit (Roche Molecular Biochemicals) and quantified fluorometrically (PicoGreen, Molecular Probes). Forty nanograms of PCR product was loaded on $6 \%$ polyacrylamide gels (acrylamide:N,N'-methylenebisacrylamide 37:1) containing a denaturant gradient, top to bottom (where $100 \%$ is defined as $7 \mathrm{M}$ urea and $40 \% \mathrm{vol} / \mathrm{vol}$ formamide). Electrophoresis was performed with the D Gene System (Bio-Rad) using $1 \times$ Tris-acetate-EDTA (TAE) running buffer (Bio-Rad) at $60^{\circ} \mathrm{C}$ for $6 \mathrm{~h}$ at $150 \mathrm{~V}$. Gels were stained for $30 \mathrm{~min}$ in SYBR Green I nucleic acid stain (1:10000 dilution; Molecular Probes), de-stained for $15 \mathrm{~min}$ in distilled water and photographed on a $302 \mathrm{~nm}$ wavelength UV table (Transilluminator 2000, Bio-Rad) through a sandwich of 3 optical filters (SYBR Green filter, Molecular Probes; Wratten 2B, Kodak; BG 39, Schott) using a digital camera (DC265 Zoom, Kodak). Dendrograms were constructed from DGGE banding patterns by the software Quantity One 4.2.1 (Bio-Rad) using the Dice coefficient and the unweighted pair-group method using arithmetic average (UPGMA) cluster analysis. DGGE bands were visually detected, and presence and position of bands were employed in the similarity analyses.
Concentration of viruses for PFGE. Viruses were concentrated from 1 to $10 \mathrm{l}$ of seawater using a slightly modified version of the protocol provided by Steward (2000). Samples were filtered through a $0.2 \mu \mathrm{m}$ capsule filter (Advantec MFS) and the content of the filtrate was then concentrated into 100 to $200 \mathrm{ml}$ using a tangential flow filtration system (100000 MWCO Prep/ Scale-TFF Cartridge, Millipore). This primary concentrate was then $0.2 \mu \mathrm{m}$ filtered into $15 \mathrm{ml}$ centrifugal ultrafiltration units (100 000 MWCO, Millipore) and further concentrated to a volume of 1 to $5 \mathrm{ml}$ by repeated rounds of centrifugation. The final volume was doubled by the addition of MSM buffer $(450 \mathrm{mM} \mathrm{NaCl}, 50 \mathrm{mM}$ $\mathrm{MgSO}_{4}, 50 \mathrm{mM}$ Tris, $0.01 \%$ gelatin, $\mathrm{pH}$ 8), preserved with $0.2 \mu \mathrm{m}$ filtered $\mathrm{Na}$-azide ( $0.1 \%$ final) and stored at $4^{\circ} \mathrm{C}$ in the dark. Due to the presence of unknown polymeric material, the viral concentrates needed to be purified before electrophoresis. First, the concentrate was centrifuged $\left(5000 \times g, 5 \mathrm{~min}, 20^{\circ} \mathrm{C}\right)$ to remove any particulate material. Then 1 to $2 \mathrm{ml}$ of the viruscontaining supernatant was layered over a cushion of $2 \mathrm{ml} 40 \%$ (bottom) and $2 \mathrm{ml} 5 \%$ glycerol in MSM buffer in polyallomer tubes and ultracentrifuged $(30000 \mathrm{rpm}$ [85000 $\times g] 20^{\circ} \mathrm{C}, 98 \mathrm{~min}$, SW55 rotor, Beckman). Under these conditions particles with a sedimentation coefficient $>100 \mathrm{~S}$ should pellet (manufacturer's instructions). The supernatant was aspirated, leaving $~ 100 \mu l$ liquid. MSM buffer $(100 \mu \mathrm{l})$ and Na-azide (0.1\% final) were added, and the virus pellet was resuspended with gentle shaking at $4{ }^{\circ} \mathrm{C}$ overnight. The virus concentration was determined microscopically (described below). Before electrophoresis, $5 \times 10^{9}$ viruses were transferred to $0.5 \mathrm{ml}$ centrifugal ultrafiltration units $(100000 \mathrm{MWCO}$, Millipore), where the buffer was exchanged with TE, viruses were further concentrated and their DNA was released by heating at $50^{\circ} \mathrm{C}$ followed by immediate cooling on ice.

PFGE and gel analysis. Viral genomes vary in length over a wide size range (reported sizes of marine viruses have been summarized in Steward et al. 2000, but see Larsen et al. 2001). By use of PFGE it is possible to resolve the distribution frequency of the viral genome sizes, which is then used to characterize the viral community. Five microliters of $6 \times$ loading buffer ( $0.25 \%$ bromphenolblue, $30 \%$ glycerol) was added (giving a final volume of $\sim 25 \mu \mathrm{l}$ ) and the sample was loaded onto a $1 \%$ agarose gel (PFGE grade agarose, Bio-Rad). Viral DNA was electrophoresed using the CHEF DR-III system (Bio-Rad) and the following conditions: $0.5 \times$ TBE gel and running buffer $(1 \times \mathrm{TBE}$ : $89 \mathrm{mM}$ Tris, $2 \mathrm{mM}$ EDTA, $89 \mathrm{mM}$ boric acid, $\mathrm{pH}$ 8.3), 1 to $5 \mathrm{~s}$ switch time, $6 \mathrm{~V} \mathrm{~cm}^{-1}, 120^{\circ}$ angle, $14^{\circ} \mathrm{C}$ and 17 $\mathrm{h}$ running time. A load of $5 \times 10^{9}$ viruses lane ${ }^{-1}$, which corresponds to approximately $380 \mathrm{ng}$ of DNA (PicoGreen DNA quantification, data not shown), was found 
to be optimal for our samples. Molecular weight markers were an 8 to $48 \mathrm{~kb}$ ladder (Bio-Rad) and a lambda ladder (Amersham Pharmacia Biotech). Gels were stained with SYBR Green I for $1 \mathrm{~h}$, destained for $30 \mathrm{~min}$ in distilled water and photographed as described above. In 2 cases, the digital gel picture was analyzed using the software Quantity One 4.2.1 to determine the proportions of virus-like genomes in a number of defined size classes. The density distribution in a lane was divided by the total density within the lane. The region bracketed by the largest and smallest DNA size standards was divided into 29 subregions of identical area. The density within each subregion was divided by an average molecular size in the region. This number was expressed as a percentage of the total area bordered by the DNA standard.

Bacterial and viral abundance. Aliquots (0.5 to $1 \mathrm{ml}$ ) fixed with $0.2 \mu \mathrm{m}$ filtered formalin ( $2 \%$ final) were filtered onto $0.02 \mu \mathrm{m}$ Anodisc filters (Whatman), stained with SYBR Green I and mounted in glycerol as described by Noble \& Fuhrman (1998). More than 200 bacteria or viruses filter ${ }^{-1}$ (or $>15$ fields filter ${ }^{-1}$ ) were counted at $1000 \times$ using epifluorescence microscopy (Olympus BH-2). To estimate variability among filters, duplicate filters were counted on 3 occasions. The standard deviation among filters was on average 3.5 and $7.5 \%$ for viruses and bacteria, respectively.

Bacterial production. Bacterial production was measured by $\left[{ }^{3} \mathrm{H}\right]$-thymidine incorporation (Fuhrman \& Azam 1982). For each sample, triplicate aliquots $(10 \mathrm{ml})$ and a fixed blank were incubated with [methyl${ }^{3} \mathrm{H}$ )-thymidine (10 $\mathrm{nM}$ final, Amersham Pharmacia Biotech) in polyethylene vials for $\sim 1 \mathrm{~h}$. Formalin $(2 \%$ final) was added to the blank prior to the addition of ${ }^{3} \mathrm{H}$-thymidine. Samples were filtered onto $0.2 \mu \mathrm{m}$ mixed cellulose ester filters (Advantec MFS), rinsed carefully with ice-cold $5 \%$ trichloroacetic acid and counted by liquid scintillation spectrometry. Bacterial carbon production was calculated using $1.1 \times 10^{18}$ cells $\mathrm{mol}^{-1}$ thymidine incorporated (Riemann et al. 1987) and a carbon to cell ratio of $20 \mathrm{fg} \mathrm{C}^{\text {bacterium }^{-1}}$ (Lee \& Fuhrman 1987).

Chl $\boldsymbol{a}$ and phytoplankton cell counts. Samples (1 to $21)$ from Roskilde Fjord were filtered onto glass fiber filters (GF/F, Whatman) and frozen. Chl a was extracted in $96 \%$ ethanol and measured spectrophotometrically according to Jespersen \& Christoffersen (1987). Samples $(100 \mathrm{ml})$ from Kattegat were treated in the same way as the samples from Roskilde Fjord but were measured fluorometrically. Fluorometer and spectrophotometer values were correlated using the samples from Roskilde Fjord. For phytoplankton enumeration, samples from Stn 413 were fixed with Lugol's solution and cells were enumerated with an inverted microscope using sedimentation chambers.
Hydrolytic extracellular enzyme activities. Hydrolytic activity of bacteria was measured in samples from Kattegat depth profiles as potential aminopeptidase activity (Hoppe et al. 1988). Triplicate subsamples (4 ml) were incubated for 3 to $4 \mathrm{~h}$ with $250 \mu \mathrm{M}$ of the fluorogenic substrate L-leucine-4-methyl-coumarinylamid (leu-MCA) to determine potential hydrolysis rates. Rates were determined from the increase in fluorescence during incubation caused by hydrolysis of leu-MCA to the highly fluorescent 7-amino-4-methylcoumarin (AMC). Measurements of enzyme kinetics and calculation of maximum uptake rate $\left(V_{\max }\right)$ ensured that the substrate (leu-MCA) was added at saturating concentrations.

\section{RESULTS}

\section{Skagerrak-Kattegat plume front}

Samples were obtained from 3 to $5 \mathrm{~m}$ and from 15 to $20 \mathrm{~m}$ depths at 5 stations in a transect crossing the front (Fig. 2). The front was characterized by relatively steep gradients in salinity both horizontally and vertically, as indicated by the decreasing surface salinity from Stn 1 toward Stn 5 and the formation of a steep halocline at Stns 3, 4 and 5. A thermocline was not fully formed at this time of year. Measurements of microbial abundance and activity as well as chl a showed some variation between samples (Table 1), but no systematic differences were observed between water masses along the transect or with depth. However, the outermost surface sample from Skagerrak (Table 1, Stn 1) did seem to have lower bacterial abundance and production. Bacterial community analyses showed the presence of unique bacterial phylotypes in the 2 water masses (Fig. 3B). One band appeared to be unique to Skagerrak water (band 1, Stn 1), but it is difficult to discern from bands in the Kattegat surface samples (Stns 4 and 5). Several bands were primarily associated with the low-salinity Kattegat water, for instance, band 5 , which was only found in surface samples at Stns 2 to 5 , and bands 2, 3 and 4 , which were found at $5 \mathrm{~m}$ depth at Stn 2 and in all samples from Stns 3 to 5. Further south at Stns 4 and 5, the number of discernible bands doubled compared to samples from Skagerrak water (28 to 29 vs 14 bands) and several distinct bands (e.g. 6, 7 and 8) appeared solely in the low-salinity surface water. At Stn 5, several unique bands appeared (e.g. bands 9 and 10). Notably, 1 bright band (band 11) was observed in all samples. As expected from the visual inspection of the gel, similarity analysis revealed a pronounced effect of the 2 different water masses on the dendrogram branching pattern (Fig. 3D). The surface samples from Stns 4 and 5 clustered on a distinct 
Table 1. Sampling locations and depths at the transect crossing the Skagerrak-Kattegat plume front May 2 to 3, 2000. Data are mean \pm standard deviations. BP: bacterial production; Chl a: chlorophyll a

\begin{tabular}{|c|c|c|c|c|c|c|c|}
\hline Stn & Latitude & Longitude & $\begin{array}{l}\text { Depth } \\
\text { (m) }\end{array}$ & $\begin{array}{c}\text { Chl a } \\
\left(\mu \mathrm{g} \mathrm{l}^{-1}\right)\end{array}$ & $\begin{array}{c}\text { Virus } \\
\left(\times 10^{7} \mathrm{ml}^{-1}\right)\end{array}$ & $\begin{array}{l}\text { Bacteria } \\
\left(\times 10^{6} \mathrm{ml}^{-1}\right)\end{array}$ & 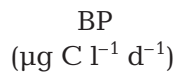 \\
\hline \multicolumn{8}{|l|}{ Upper waters } \\
\hline 1 & $57^{\circ} 54.22^{\prime} \mathrm{N}$ & $10^{\circ} 43.82^{\prime} \mathrm{E}$ & 5 & 0.89 & $5.2 \pm 0.2$ & $0.3 \pm 0.0$ & $4.3 \pm 0.4$ \\
\hline 2 & $57^{\circ} 48.96^{\prime} \mathrm{N}$ & $10^{\circ} 43.35^{\prime} \mathrm{E}$ & 5 & 3.19 & $5.5 \pm 0.2$ & $1.8 \pm 0.1$ & $12.5 \pm 0.9$ \\
\hline 3 & $57^{\circ} 45.61^{\prime} \mathrm{N}$ & $10^{\circ} 43.45^{\prime} \mathrm{E}$ & 5 & 2.41 & $5.3 \pm 0.2$ & $1.6 \pm 0.1$ & $23.4 \pm 4.9$ \\
\hline 4 & $57^{\circ} 42.20^{\prime} \mathrm{N}$ & $10^{\circ} 43.46^{\prime} \mathrm{E}$ & 3 & 3.79 & $5.1 \pm 0.2$ & $2.0 \pm 0.2$ & $15.2 \pm 0.5$ \\
\hline 5 & $57^{\circ} 38.80^{\prime} \mathrm{N}$ & $10^{\circ} 43.53^{\prime} \mathrm{E}$ & 3 & 3.30 & $4.0 \pm 0.1$ & $1.6 \pm 0.1$ & $12.8 \pm 0.2$ \\
\hline \multicolumn{8}{|l|}{ Lower waters } \\
\hline 2 & & & 20 & 3.25 & $7.3 \pm 0.3$ & $1.5 \pm 0.1$ & $3.7 \pm 0.5$ \\
\hline 3 & & & 20 & 2.57 & $3.1 \pm 0.1$ & $1.6 \pm 0.1$ & $12.1 \pm 0.9$ \\
\hline 4 & & & 15 & 2.67 & $2.8 \pm 0.1$ & $2.0 \pm 0.2$ & $12.0 \pm 1.0$ \\
\hline 5 & & & 15 & 2.99 & $4.2 \pm 0.2$ & $0.8 \pm 0.1$ & $4.2 \pm 0.2$ \\
\hline
\end{tabular}

Relative density St. 3, $20 \mathrm{~m}$ \begin{tabular}{rr}
$200 \quad 100$ \\
\hline
\end{tabular}
A

(k)

A

DNA St. $1 \quad$ St. $2 \quad$ St. 3 stand. $5 \mathrm{~m} \quad 5 \mathrm{~m} 20 \mathrm{~m} \quad 5 \mathrm{~m} \quad 20 \mathrm{~m}$ St. 4 St. 5 (kb)

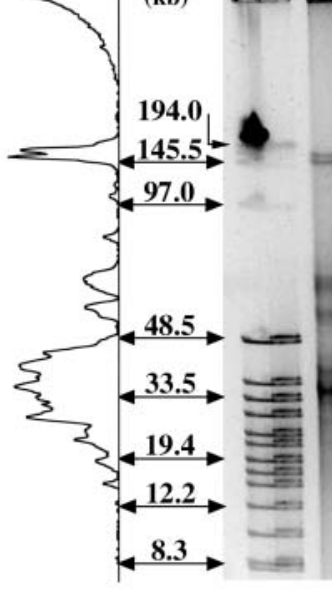

D

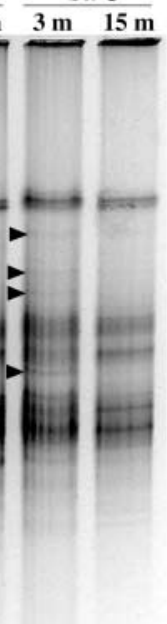

\section{B}

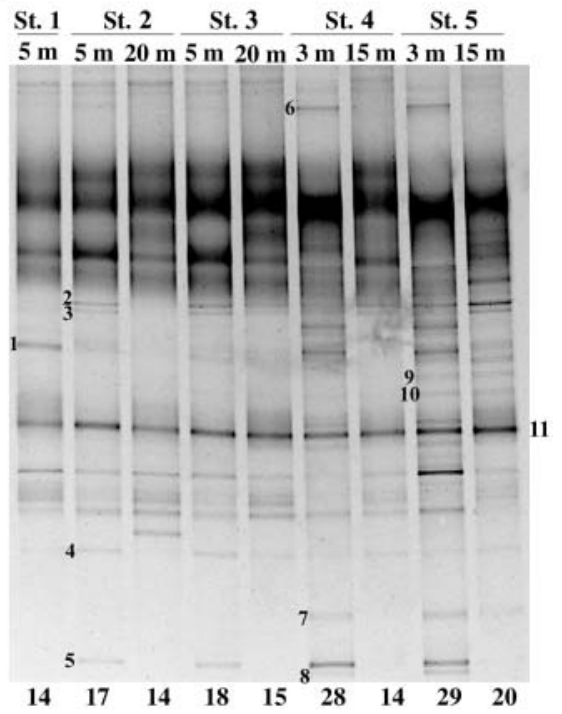

C

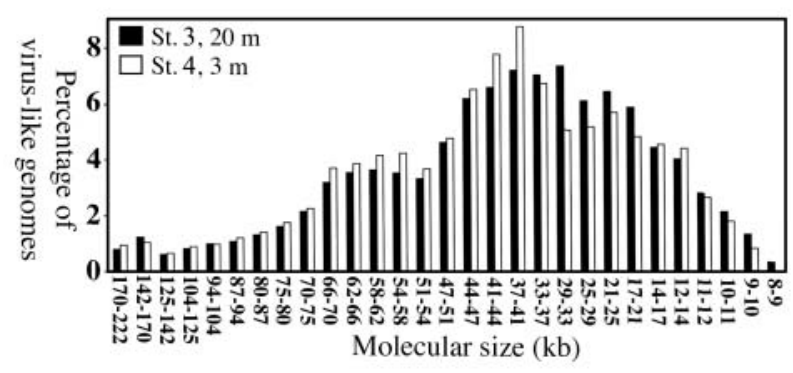

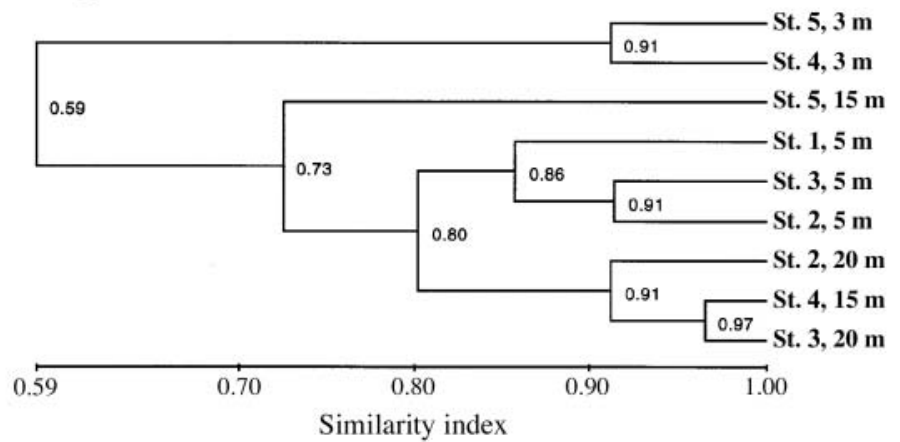

Fig. 3. (A) Pulsed field gel electrophoresis (PFGE) and (B) denaturing gradient gel electrophoresis (DGGE) gels of samples obtained across the Skagerrak-Kattegat plume front. Stations and depths are indicated above the gels. Bands of specific interest in each gel are marked by arrowheads, brackets or numbers and are referred to in the text. The DNA standards used in the PFGE was a mix of lambda and 8 to $48 \mathrm{~kb}$ ladders. (A) A vertical density profile of the sample from $20 \mathrm{~m}$ depth at Stn 3 as depicted by gel analysis software is shown as a function of molecular weight to the left of the PFGE gel. (B) A denaturing gradient top to bottom of 27 to $47 \%$ was applied in DGGE. (C) The density profiles of 2 samples were converted to relative percentage of viruses in arbitrarily defined size regions (see 'Materials and methods'). (D) The number of discernible DGGE bands applied in construction of the dendrogram is shown below each lane 
branch showing low similarities to the rest of the samples. Also, the deep-water sample at Stn 5 appeared on a distinct branch. At the rest of the stations, samples from above and below the halocline appeared in distinct clusters. Notably, Stn 1 had a low similarity to the nearest stations (Stns 2 and 3).

Virus-like genomes were dominated by 3 distinct size classes: a profound high-density region at 33 to $48 \mathrm{~kb}$, another high-density region at 50 to $60 \mathrm{~kb}$, and distinct bands in the 145 to $194 \mathrm{~kb}$ region (Fig. 3A,C). As an example, the density of the $20 \mathrm{~m}$ PFGE lane from Stn 3 is plotted as a function of molecular weight (Fig. 3A). Besides the peak in density at the top of the gel, the 3 high-density regions are seen as distinct peaks. The size distribution of virus-like genomes in samples from above and below the halocline changed in a fashion comparable to the DGGE patterns of bacterial phylotypes. Two bands in the upper part (arrowheads) and 4 bands in the lower part (brackets) of the gel were present in samples from Stns 2 and 3, and in deep-water samples from Stn 4, but were not present in the Kattegat surface samples (Stns 4 and 5). Four bands (arrowheads) appeared to be unique to the surface samples from Stns 4 and 5.

\section{Depth profiles}

At Stn 413, the CTD profile showed a pronounced fluorescence peak at the lower boundary of the pycnocline (Fig. 4A). Chl a measurements varied 5-fold across the $3 \mathrm{~m}$ depth interval from 3 to $4 \mu \mathrm{g} \mathrm{l}^{-1}$ to the

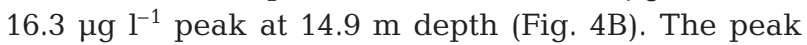
was dominated by a coccolithophorid resembling Emiliania huxleyi ( $>95 \%$ of cell counts at $14.9 \mathrm{~m}$ ), which increased in abundance from 150 cells ml$^{-1}$ at $13.3 \mathrm{~m}$ to the highest concentration of 23150 cells ml$^{-1}$ at $14.9 \mathrm{~m}$ (data not shown). Whereas bacterial and viral abundances were relatively stable with depth (range $1.3 \times$ $10^{6}$ to $2.2 \times 10^{6} \mathrm{ml}^{-1}$ and $3.8 \times 10^{7}$ to $5.6 \times 10^{7} \mathrm{ml}^{-1}$, respectively; Fig. 4B) larger differences were observed in bacterial activity. Patterns in bacterial production and protease activity were similar and seemed to be inversely correlated to chl a (Fig. 4C). Bacterial production increased 3.5 -fold from $13.3 \mathrm{~m}$ to the peak at $14.0 \mathrm{~m}\left(35.5 \mu \mathrm{g} \mathrm{C} \mathrm{l}^{-1} \mathrm{~d}^{-1}\right)$ and then declined as chl $a$ concentration increased. Bacterial production and protease activity increased again below the chl a peak. DGGE analysis revealed that most phylotypes were found throughout the $3 \mathrm{~m}$ depth interval; however, 3 additional bands appeared and 1 band increased significantly in density at the depth with highest bacterial production and protease activity (arrowheads in Fig. 5A). The presence of most bands at all depths is reflected in the high similarity values depicted in the
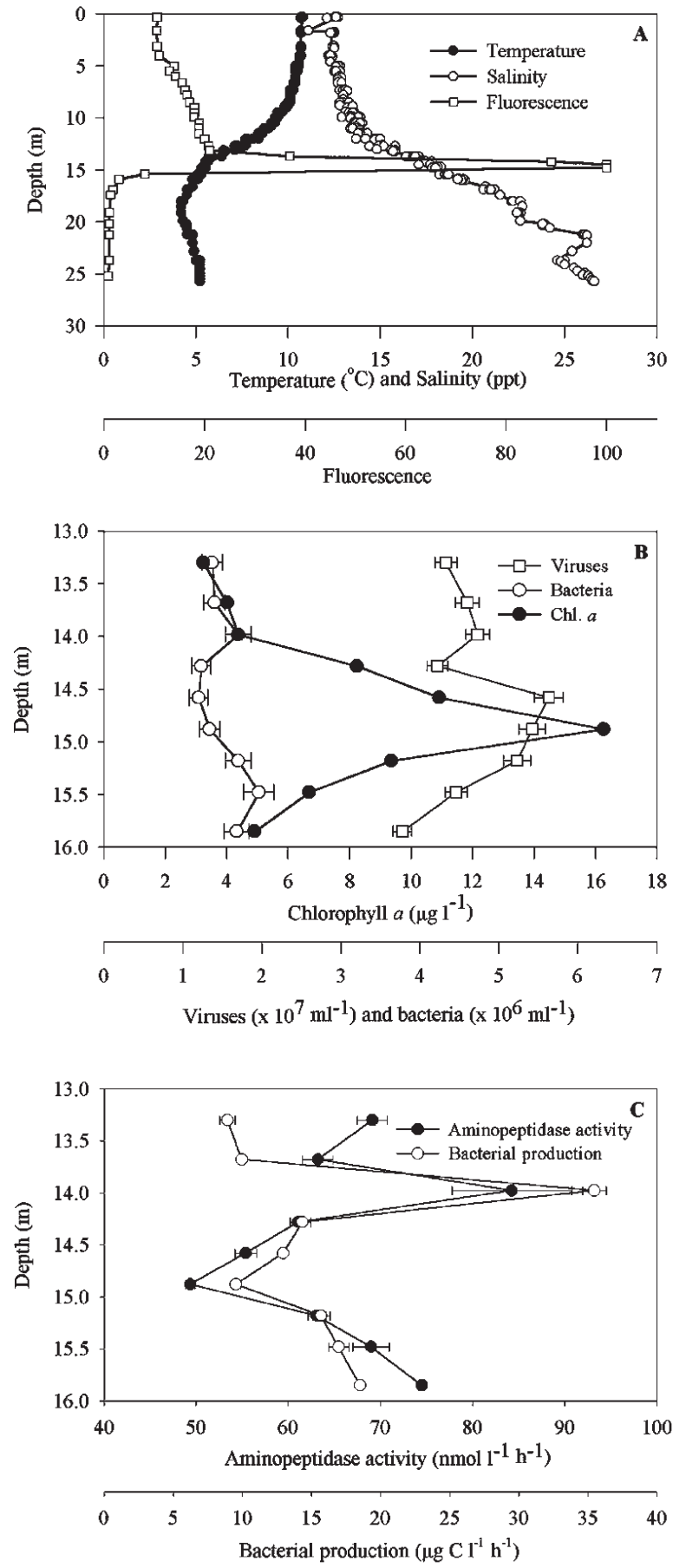

Fig. 4. (A) CTD probe depth profile of temperature, salinity and fluorescence, (B) measurements of viral and bacterial abundances and chlorophyll a (Chl. a) and (C) bacterial production and extracellular aminopeptidase activity in samples obtained from Stn 413 in Kattegat. Note the different scales within and between panels

dendrogram. PFGE analysis of virus-like genomes revealed a number of distinct bands, but no significant changes in viral community composition could be detected with depth (Fig. 5B). The size-class distribution 
A

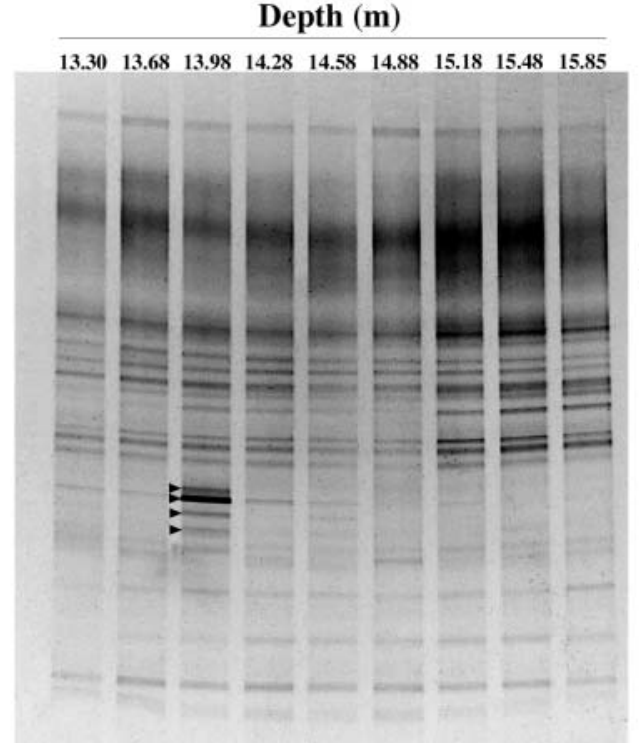

B

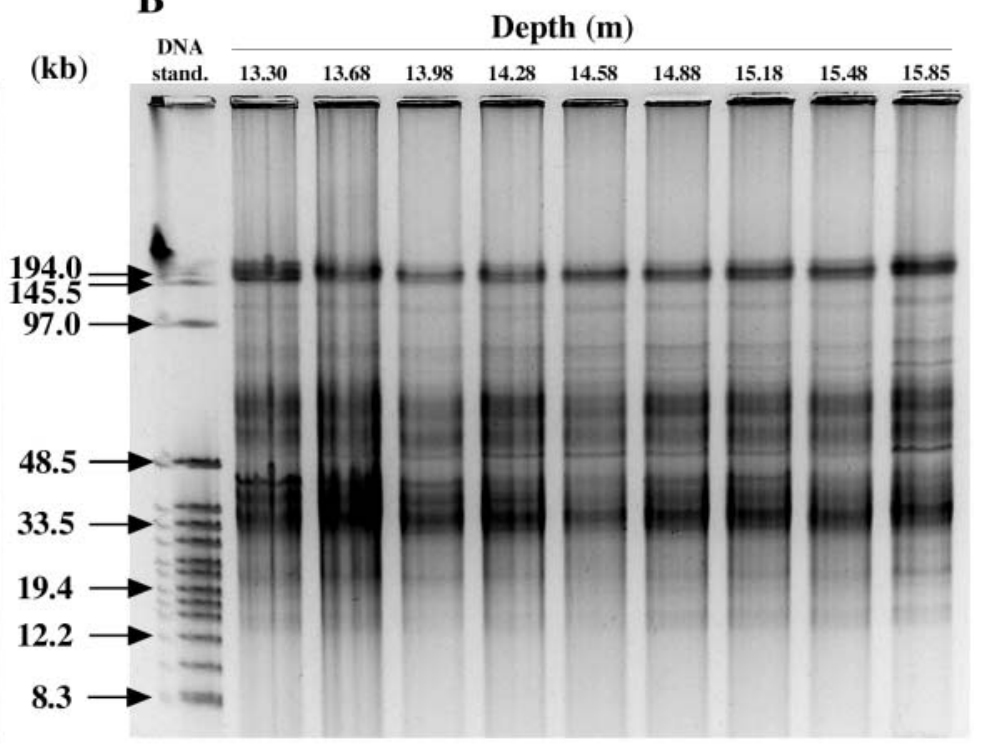

$\begin{array}{lllllllll}17 & 18 & 21 & 19 & 20 & 18 & 19 & 18 & 18\end{array}$

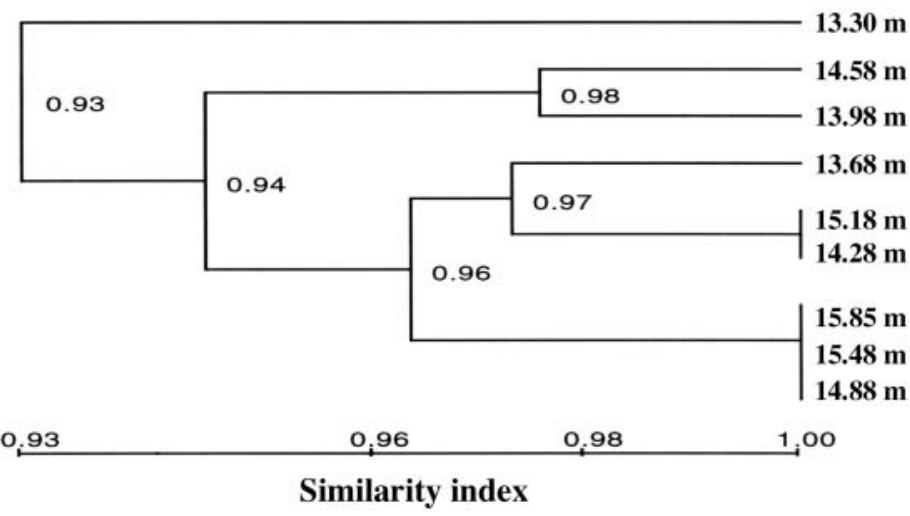

Fig. 5. (A) DGGE and (B) PFGE gels of samples from the depth profile at Stn 413 in Kattegat. (A) A denaturing gradient top to bottom of 26 to $50 \%$ was applied in DGGE. Appearance of bands and a marked change in density of a single band concomitantly with the peak in bacterial activity (Fig. 2C) is indicated by arrows. The number of discernible DGGE bands applied in construction of the dendrogram (C) is seen below the gel. (B) The DNA standards used in the PFGE is a mix of lambda and 8 to $48 \mathrm{~kb}$ ladders of virus-like genomes was similar to that of samples from the Skagerrak-Kattegat front and Roskilde Fjord.

\section{Roskilde Fjord}

Chl a increased from low values in late February $\left(\sim 3 \mu \mathrm{g} \mathrm{l}^{-1}\right)$ to the peak of the phytoplankton spring bloom in late March ( $28 \mu \mathrm{g} \mathrm{l}^{-1}$; Fig. 6A). Bacterial and viral abundances were high but variable throughout the sampling period (Fig. 6B). Viral abundance was high in late February $\left(18 \times 10^{7} \mathrm{ml}^{-1}\right)$ but then declined rapidly to the lowest value on March $14\left(3 \times 10^{7} \mathrm{ml}^{-1}\right)$. Bacterial abundance was $6 \times 10^{6} \mathrm{ml}^{-1}$ in late February but increased to $13 \times 10^{6} \mathrm{ml}^{-1}$ as the phytoplankton bloom developed. Bacterial production was low in late February $\left(5 \mu \mathrm{g} \mathrm{Cl}^{-1}\right.$ $\mathrm{d}^{-1}$ ) but increased to $58 \mathrm{\mu g} \mathrm{Cl}^{-1} \mathrm{~d}^{-1}$ right before the peak in chl a (Fig. 6A). Abundances and bacterial production decreased concomitantly with the early decline of the bloom but then increased steadily during the postbloom phase. The temperature increased from 3 to $12^{\circ} \mathrm{C}$ during the sampling period with a $5^{\circ} \mathrm{C}$ increase during the postbloom phase. Salinity was 12 to $13 \%$ o throughout the sampling period. Only a few changes in the size distribution of virus-like genomes were discernible on the PFGE gels (arrowheads in Fig. 7A). DGGE profiles also showed a large similarity in banding patterns throughout the spring bloom period. However, 2 bands appeared in the period with the highest phytoplankton biomass (arrowheads in Fig. 7B), and changes were observed in band densities. Most notable are the 4 bands at the lower end of the DGGE gel, which increased significantly in density prior to the peak of the bloom, and 2 very dense bands at the upper part of the gel, which peaked in density as the bloom peaked. Although few differences in the presence of bands were observed among samples, these changes appeared to be systematic when subjected to similarity analysis. Samples from the phyto- 

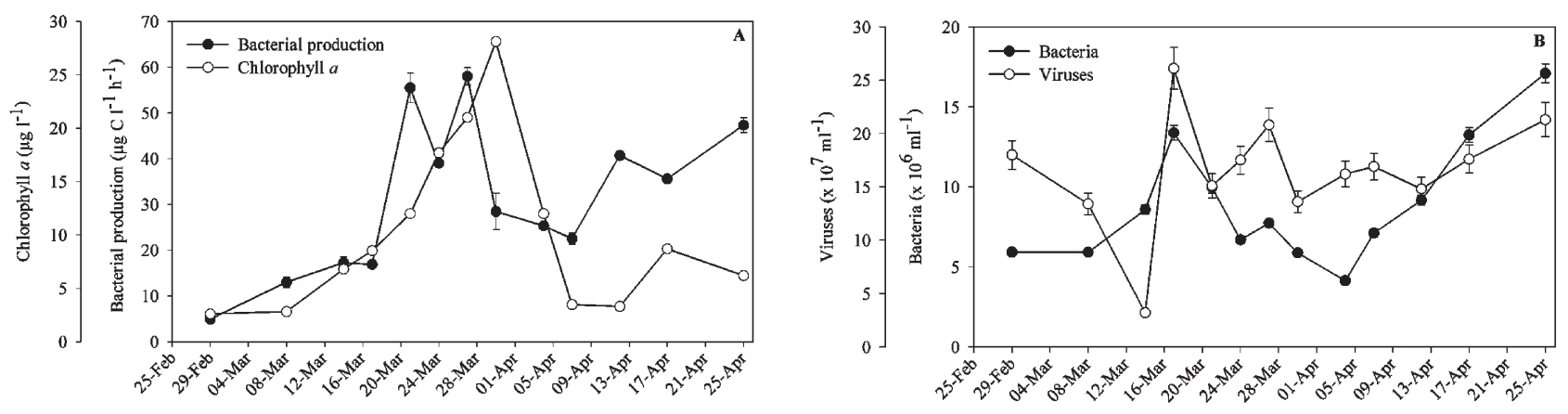

Fig. 6. (A) Chlorophyll a concentration and bacterial production and (B) bacterial and viral abundances during the course of the phytoplankton spring bloom in Roskilde Fjord

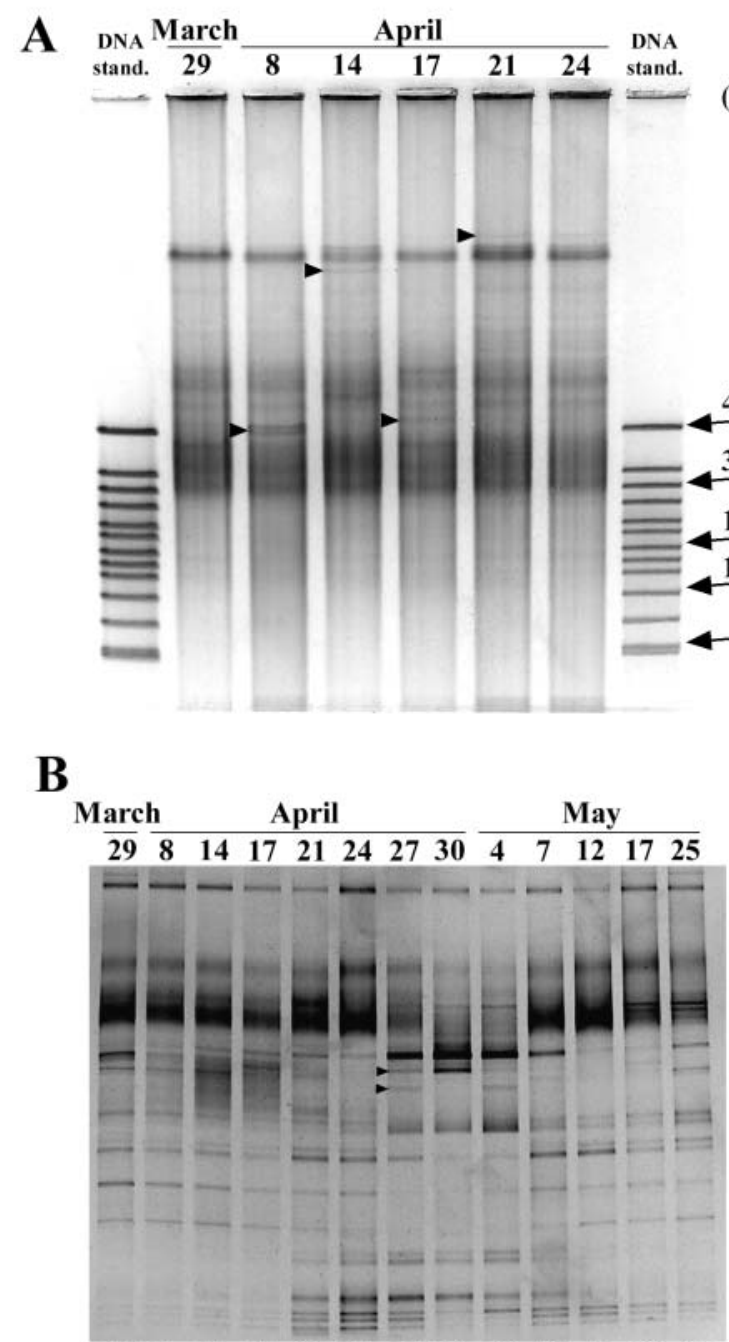

$\begin{array}{lllllllllllll}19 & 17 & 17 & 17 & 19 & 19 & 19 & 18 & 19 & 20 & 20 & 18 & 19\end{array}$

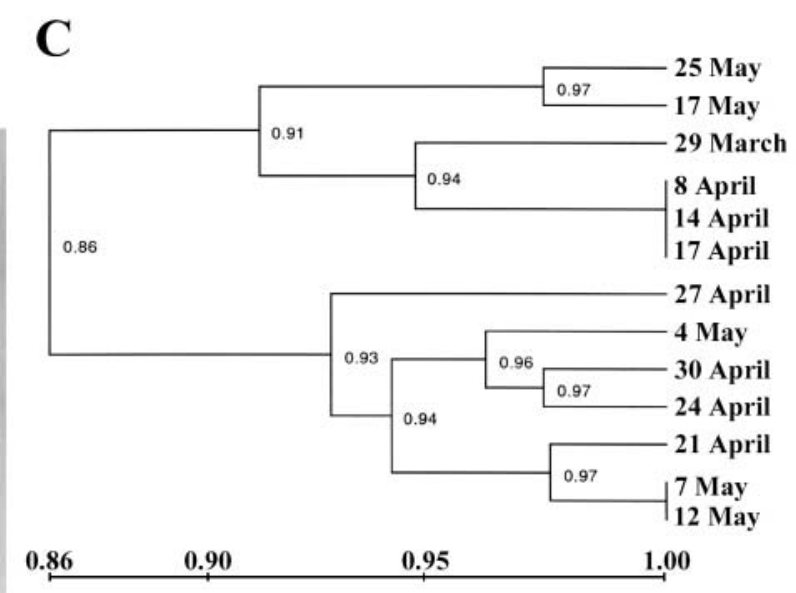

Similarity index

Fig. 7. (A) PFGE and (B) DGGE gels of samples obtained during the course of the phytoplankton spring bloom in Roskilde Fjord. Dates of sampling are indicated above the gels. Bands of specific interest in each gel are marked by arrowheads and are referred to in the text. The sample from May 17 was not analyzed on PFGE due to bacterial contamination of the viral concentrate. The DNA standard used in the PFGE is an 8 to $48 \mathrm{~kb}$ ladder. A denaturing gradient top to bottom of 28 to $49 \%$ was applied in DGGE.

The number of discernible DGGE bands applied in construction of the dendrogram (C) is shown below each lane 
plankton bloom period clustered on a separate branch from samples obtained before and after the bloom; however, the similarities between samples were high (Fig. 7C).

\section{DISCUSSION}

\section{Methodological considerations}

Whereas PCR-DGGE is now widely used in microbial ecology, and the potential limitations and biases well known (Muyzer et al. 1998, Ferrari \& Hollibaugh 1999, Riemann et al. 1999), PFGE analysis of virus-like genomes has recently been introduced in aquatic microbial ecology (Wommack et al. 1999a,b, Steward \& Azam 2000, Steward et al. 2000). The ability of PFGE to resolve changes in the size distribution of virus-like genomes within natural samples has been demonstrated previously and the detection limit can be as low as $10^{6}$ viruses band ${ }^{-1}$ (Wommack et al. 1999b, Steward et al. 2000). Different viruses could have the same genome size and therefore be indistinguishable on a PFGE gel; therefore, it should be noted that PFGE gives a rough minimum estimate of viral diversity, where some community changes might not be detected.

Several important biases and limitations might affect PFGE patterns (see detailed description by Steward et al. 2000). One limitation is that mainly viruses with double-stranded (ds) DNA are detected with SYBR Green I fluorescent stain because the sensitivity toward RNA or single-stranded (ss) DNA is much lower than that toward dsDNA (Molecular Probes). We applied $0.2 \mu \mathrm{m}$ prefiltration and tangential flow ultrafiltration for concentrating viruses. Although most marine viruses are <0.2 $\mu \mathrm{m}$ (Børsheim 1993, Weinbauer \& Peduzzi 1994), some very large viruses have been found (Bratbak et al. 1992). We did not specifically test for this potential bias in our samples; however, the loss of large viruses might have been significant. Optimal electrophoresis conditions were determined empirically, and we chose conditions (especially switch time) providing maximum separation of DNA in the size range 10 to $200 \mathrm{~kb}$. Most virus-like genomes from natural samples have been found in this size range (Wommack et al. 1999a,b, Steward et al. 2000, Larsen et al. 2001); however, the used electrophoresis conditions could potentially have compromised the separation of larger DNA. Although no DNA is visible at the uppermost parts of the PFGE gels (except in the wells), we cannot unambiguously exclude the possibility that large genomes were not separated. In this context, it should noted that Castberg et al. (2001) and Larsen et al. (2001) recently observed viruses (presumably phytoplankton viruses) with ge- nome sizes up to $>400 \mathrm{~kb}$ during the course of phytoplankton blooms.

During electrophoresis, we had severe problems with supposedly polymeric material in the viral concentrates obstructing DNA migration. An additional low-speed glycerol ultracentrifugation of the viral concentrates helped for almost all samples (but see lanes 1 and 2, Fig. 5B). This centrifugation removes a large part of dissolved DNA (Jiang \& Paul 1995), presumably along with other polymers obstructing electrophoresis. Similar problems with polymeric material have occurred in samples from Mono Lake, California (G. F. Steward pers. comm.) but have not been reported for marine waters. In addition, the resolution of PFGE bands in some samples (e.g. Roskilde Fjord) remained poor despite numerous attempts to optimize the size separation. A possible explanation is that the viral community, especially in eutrophic Roskilde Fjord, had very high species diversity. A vast number of PFGE bands representing a continuum of size classes of virus-like genomes would be seen as a smear.

\section{Transect across the Skagerrak-Kattegat plume front}

The salinity characteristics across the front shows that the 2 water masses (Kattegat and Skagerrak) are separated by steep salinity gradients (Fig. 2). We suggest that the observed patterns in bacterial community compositions reflect the presence of discrete communities in the 2 water masses (Fig. 3). However, the nonuniform distribution of the specific 'Kattegat phylotypes' (compare bands 2 to 5 vs 6 to 8 vs 9 to 10, Fig. 3) at the different stations toward Skagerrak indicate that the distribution of bands cannot be explained solely by mixing of the 2 water masses but also may be influenced by community successions in response to the local environments. The differences in community composition between samples illustrates that similar levels of chl a, microbial abundance and bacterial production do not necessarily lead to similar community structures of bacterial and viral assemblages. The similarities of the DGGE pattern in the 2 water masses may be the result of the gradual mixing across the front (Figs. $2 \& 3$ ) but may also reflect ubiquity of certain bacterial phylotypes.

The differences in the size distribution of virus-like genomes between the 2 water masses support the suggestive pattern observed for bacterial community composition. Specific viral phylotypes were associated with each water mass; however, the differences were less pronounced. As exemplified by the vertical density plot in Fig. 3A, the density of the size regions changing between samples was a minor part of the total density within a lane. Thus, most viral genome 
sizes were present in both water masses, suggesting that a large fraction of the viral community is ubiquitous in Danish coastal waters. However, it should be noted that if the density of bands is converted into a relative number of viruses, then the genome size has to be taken into account. To illustrate this, we converted the density in the PFGE profiles at $20 \mathrm{~m}$ from Stn 3 and at $3 \mathrm{~m}$ from Stn 4 into the relative number of viruses in different size classes (Fig. 3C). The relative size distribution is similar to that reported by Steward et al. (2000) with peaks in the $\sim 29$ to 47 , $\sim 54$ to 70 and $\sim 142$ to $222 \mathrm{~kb}$ regions. Differences between the 2 stations were most pronounced in the $\sim 17$ to $47 \mathrm{~kb}$ region. The histogram illustrates the presence of the distinct bands in the $20 \mathrm{~m}$ profile at Stn 3 (see brackets in Fig. 3A), which accounts for a difference of approximately $5 \%$ of the total viral genome number in the region bordered by the DNA standard.

\section{Depth profiles}

The negative relation between algal biomass and bacterial activity (i.e. bacterial production and protease activity) across the pycnocline (Fig. 4B,C) suggested that the coccolithophorid subsurface bloom inhibited bacterioplankton growth. However, to our knowledge, no negative effects on bacterioplankton growth have so far been reported for coccolithophorids. On the contrary, peaks in bacterial abundance and production have been found to occur almost synchronously with the maxima in algal abundance during a marine mesocosm bloom experiment dominated by the coccolithophorid Emiliania huxleyi (Sanders \& Purdie 1998). However, it should be mentioned that a grazing-activated chemical defense mechanism against protozoan predators has been observed for E. huxleyi (Wolfe et al. 1997). Reduced bacterial production rates have previously been observed in association with subsurface blooms of the dinoflagellate Gyrodinium aureolum (Bjørnsen \& Nielsen 1991) and of the mixotrophic haptophycean Chrysochromulina polylepis (Nielsen et al. 1990) in the southern Kattegat. However, in contrast to E. huxleyi, both of these algal species are known to be potentially toxic. Bacterial activity peaked at $13.98 \mathrm{~m}$ depth (Fig. 4C), where also 3 DGGE bands appeared and 1 DGGE band showed a pronounced increase in density (arrowheads in Fig. 5A). Bacterial abundance, on the other hand, did not vary significantly with depth, and these bands may, therefore, represent bacterial phylotypes taking advantage of specific local substrate conditions by increasing their proportion of the bacterial community. While this is a likely explanation, it should be emphasized that PCR-DGGE is a semi-quantitative tool (Rie- mann et al. 1999), and that extrapolating from band density to cell numbers is speculative.

Except for the few unique DGGE bands observed in samples from the upper part of the phytoplankton peak, bacterial and viral community compositions showed only negligible changes with depth. It is notable that no differences in the size distribution of virus-like genomes were discernible despite the presence of one defined depth region with marked changes in bacterial activity and composition, and another region with a monospecific algal bloom. The appearance of characteristic phytoplankton viruses ( 180 nm in diameter) has previously been observed during the collapse of Emiliania huxleyi blooms (Bratbak et al. 1993) even at lower algal cell densities than those observed in this study (Bratbak et al. 1995). Further, in a recent paper, Castberg et al. (2001) presented direct evidence that a mesocosm bloom of $E$. huxleyi was terminated by a virus with a genome size of $425 \mathrm{~kb}$ and a particle size of $160 \mathrm{~nm}$. In the present study, there did not seem to be any particular virus population associated with the coccolithophorid bloom; however, the $0.2 \mu \mathrm{m}$ filtration before concentration and electrophoresis of viral DNA could potentially explain why such large viruses where not detected.

\section{Spring bloom in Roskilde Fjord}

Pronounced changes in microbial abundances and bacterial production were observed during the course of the phytoplankton bloom (Fig. 6). Despite these large variations, most bacterial phylotypes persisted throughout the sampling period (Fig. 7B). This was surprising since bacterial community successions are commonly associated with formation and senescence of phytoplankton blooms (Van Hannen et al. 1999, Riemann et al. 2000, Fandino et al. 2001, Riemann \& Winding 2001, Schäfer et al. 2001), possibly reflecting the proliferation of bacterial phylotypes specialized in particle colonization and degradation (Riemann et al. 2000). Changes in band density were observed, most markedly as the bloom peaked where a few bands became very dense. Since individual DGGE bands were not sequenced, we cannot exclude that these bands may have been of phytoplankton plastid origin, as commonly observed when analyzing plankton communities by PCR-DGGE (Riemann et al. 2000, Fandino et al. 2001).

Despite large variations in environmental parameters as well as major changes (up to 8-fold) in viral abundance, only minor changes in the size distribution of virus-like genomes were observed (Fig. 7A). Our results differ somewhat from the pattern observed by Wommack et al. (1999b), who monitored viral commu- 
nity dynamics using PFGE from May to July in Chesapeake Bay. They observed a number of differences in the banding patterns between 3 samples taken at monthly intervals at different locations in the bay and suggested that these changes reflected differences in the corresponding host populations. They argued that the temporal variations in viral community composition in Chesapeake Bay were in part due to seasonality in physico-chemical changes in the water column at the locations sampled (e.g. degree of stratification; Wommack et al. 1999b). In comparison, Roskilde Fjord was unstratified and had constant salinity, and the stable viral community in the present study may, therefore, be related to constant physico-chemical conditions in the fjord. On the other hand, our observation of only minor changes in viral community composition are in contrast to recent studies showing pronounced changes in viral community structure associated with phytoplankton blooms (Steward et al. 2000, Castberg et al. 2001, Larsen et al. 2001). These studies observed significant changes in the DNA size range 10 to $200 \mathrm{~kb}$, which was the focus of the present study.

\section{Temporal and spatial dynamics in bacterial and viral community composition}

The most interesting finding of this study was that the majority of detectable bacterial phylotypes and virus-like genome sizes seemed to persist across temporal or spatial gradients despite major variations in productivity. This was surprising because of the many reports suggesting that changes in bacterial or viral community compositions are a consequence of alterations in the organic matter field or other environmental factors (Pinhassi et al. 1999, Van Hannen et al. 1999, Wommack et al. 1999a,b, Riemann et al. 2000, Steward et al. 2000, Fandino et al. 2001, Larsen et al. 2001). Our results could be interpreted as evidence for a large functional plasticity possessed by individual bacterial phylotypes in accommodating changing growth conditions. The cosmopolitan distribution of various bacterial species or clusters in the world's oceans (see Giovannoni \& Rappé 2000) provides some indirect support for resilience among bacteria to changing growth conditions. Alternative explanations to the observed stability in microbial community compositions include methodology-related aspects. Since significant differences in DGGE profiles between samples from the Skagerrak-Kattegat front were clearly discernible and the reported sensitivity of DGGE is as low as $1 \%$ of the template DNA (Muyzer et al. 1993), we do not believe that the sensitivity of the DGGE approach significantly limited the detection of changes in the composition of amplifiable $16 \mathrm{~S}$ rDNA. Although the community as a whole was similar between samples, there may have been changes in the relative activity among bacterial populations. Part of the observed variability in bulk bacterial activity may, therefore, have been associated with shifts in activity between different populations. Analyses of $16 \mathrm{~S}$ rDNA do not distinguish active and inactive bacteria; hence, changes in relative activity of individual bacterial populations within the bacterial community might not have been detected. Such changes would presumably have been revealed by $16 \mathrm{~S}$ rRNA DGGE analysis (e.g. Schäfer et al. 2001).

Our results are similar to a recent report of stable DGGE banding patterns despite large variability in other biological parameters in surface samples from the Arabian Sea (Riemann et al. 1999). The authors observed only minor differences in bacterial community composition moving from coastal to offshore stations (up to $1500 \mathrm{~km}$ apart) between samples taken 11 mo apart (Riemann et al. 1999). In contrast to the stability in microbial community composition across the short vertical gradients in Kattegat and over time in Roskilde Fjord, we found larger differences in DGGE and PFGE profiles of samples from the transect crossing the Skagerrak-Kattegat plume front (e.g. compare the similarity values in Figs. 3D, 5C \& 7C), which covered a larger spatial scale and incorporated 2 distinct water masses (Fig. 2). Our data suggest that 2 water masses with distinct physico-chemical characteristics and different history contained different bacterial and viral populations, and that the differences between the communities were blurred in the Southern Kattegat (Fig. 5), presumably due to partial mixing of the water masses. These findings support the suggestion by Wommack et al. (1999b) that the structure of viral communities may be influenced by physico-chemical changes.

Interestingly, the bacterial community dynamics in samples from the Kattegat depth profile and Roskilde Fjord were not accompanied by changes in the size distribution of virus-like genomes discernible by the present PFGE analysis. However, a direct comparison between results obtained by DGGE and PFGE is highly speculative, and more quantitative methods are required in order to thoroughly analyze virus-bacteria interactions in natural assemblages. According to the prevalent 'killing the winner' hypothesis, any dominant bacterial population would be controlled by viral lysis, leaving room for another population to become dominant, etc., thus suggesting a succession in blooms of different bacteria-virus systems (Wommack \& Colwell 2000). Indications of bloom-like changes in the abundance of single viruses have been observed in virioplankton in Chesapeake Bay (Wommack et al. 1999b); however, unambiguous evidence for such virus-host dynamics has so far only been demonstrated 
in extreme situations such as during the collapse of phytoplankton blooms (Bratbak et al. 1993, Tarutani et al. 2000, Castberg et al. 2001, Larsen et al. 2001) or during laboratory experiments with single virusbacteria systems (Middelboe 2000). In Danish coastal waters, on the other hand, we found only insignificant indications of such blooms of individual viral populations associated with the observed environmental changes or bacterial community dynamics.

Acknowledgements. The study was supported by grants from the Danish Natural Science Research Council (Grant \# 9801391) and the Carlsberg Foundation (Grants \# 990361/40-1391 and 990689/20-1307) to M.M. and by a PhD stipend from the University of Copenhagen to L.R. We are grateful to Grieg F. Steward for extensive advice on the use of PFGE and for useful comments on an earlier version of the manuscript. We thank Marina Madsen for excellent shipboard assistance, Torkel G. Nielsen for support with the gradient multi-sampler and the Danish Environmental Research Institute for permission to participate in the research cruise on board RV 'Gunnar Thorson'. We thank Bruno Hansen and Søren Hedal, Roskilde County, for obtaining a number of the water samples from Roskilde Fjord and for unpublished data on chlorophyll $a$, salinity and temperature, Niels Vinther for help with constructing Fig. 1 and Jakob Larsen for identification of the coccolithophorid.

\section{LITERATURE CITED}

Bjørnsen PK, Nielsen TG (1991) Decimeter scale heterogeneity in the plankton during a pycnocline bloom of Gyrodinium aureolum. Mar Ecol Prog Ser 73:263-267

Børsheim KY (1993) Native marine bacteriophages. FEMS Microbiol Ecol 102:141-159

Bratbak G, Haslund OH, Heldal M, Næs A, Røeggen T (1992) Giant marine viruses? Mar Ecol Prog Ser 85:201-202

Bratbak G, Egge JK, Heldal M (1993) Viral mortality of the marine alga Emiliania huxleyi (Haptophyceae) and termination of algal blooms. Mar Ecol Prog Ser 93:39-48

Bratbak G, Levasseur M, Michaud S, Cantin G and 3 others (1995) Viral activity in relation to Emiliania huxleyi blooms: a mechanism of DSMP release? Mar Ecol Prog Ser 128: 133-142

Bratbak G, Heldal M, Thingstad TF, Tuomi P (1996) Dynamics of virus abundance in coastal seawater. FEMS Microbiol Ecol 19:263-269

Castberg $T$, Larsen A, Sandaa RA, Brussaard CPD and 5 others (2001) Microbial population dynamics and diversity during a bloom of the marine coccolithophorid Emiliania huxleyi (Haptophyta). Mar Ecol Prog Ser 221:39-46

Ducklow HW, Kirchman DL, Quinby HL, Carlson CA, Dam HG (1993) Stocks and dynamics of bacterioplankton carbon during the spring bloom in the eastern North Atlantic ocean. Deep-Sea Res II 40:245-263

Fandino LB, Riemann L, Steward GF, Long RA, Azam F (2001) Variations in bacterial community structure during a dinoflagellate bloom analyzed by DGGE and 16S rDNA sequencing. Aquat Microb Ecol 23:119-130

Ferrari VC, Hollibaugh JT (1999) Distribution of microbial assemblages in the Central Arctic Ocean Basin studied by
PCR/DGGE: analysis of a large data set. Hydrobiologia 401:55-68

Fuhrman JA, Azam F (1982) Thymidine incorporation as a measure of heterotrophic bacterioplankton production in marine surface waters: evaluation and field results. Mar Biol 66:109-20

Garrity GM (ed) (2001) Bergey's manual of systematic bacteriology, 2nd edn. Springer-Verlag, New York

Giovannoni S, Rappé M (2000) Evolution, diversity, and molecular ecology of marine prokaryotes. In: Kirchman DL (ed) Mirobial ecology of the oceans. Wiley-Liss, New York, p 47-84

Heilmann JP, Richardson K, Ærtebjerg K (1994) Annual distribution and activity of phytoplankton in the Skagerrak/ Kattegat frontal region. Mar Ecol Prog Ser 112:213-223

Hoppe HG, Kim SJ, Gocke K (1988) Microbial decomposition in aquatic environments: combined process of extracellular enzyme activity and substrate uptake. Appl Environ Microbiol 54:784-790

Jespersen AM, Christoffersen K (1987) Measurements of chlorophyll-a from phytoplankton using ethanol as extraction solvent. Arch Hydrobiol 109:445-454

Jiang SC, Paul JH (1995) Viral contribution to dissolved DNA in the marine environment as determined by differential centrifugation and kingdom probing. Appl Environ Microbiol 61:317-325

Jørgensen NOG, Søndergaard M, Hansen HJ, Bosselmann S, Riemann B (1983) Diel variation in concentration, assimilation and respiration of dissolved free amino acids in relation to planktonic primary and secondary production in two eutrophic lakes. Hydrobiologia 107:107-122

Karner M, Rassoulzadegan F (1995) Extracellular enzyme activity: indications for high short-term variability in a coastal marine ecosystem. Microb Ecol 30:143-156

Karner M, Fuks D, Herndl GJ (1992) Bacterial activity along a trophic gradient. Microb Ecol 24:243-257

Larsen A, Castberg T, Sandaa RA, Brussaard CPD and 6 others (2001) Population dynamics and diversity of phytoplankton, bacteria and viruses in a seawater enclosure. Mar Ecol Prog Ser 221:47-57

Lee SH, Fuhrman JA (1987) Relationships between biovolume and biomass of naturally derived marine bacterioplankton. Appl Environ Microbiol 53:1298-1303

Martinez J, Smith DC, Steward GF, Azam F (1996) Variability in ectohydrolytic enzyme activities of pelagic marine bacteria and its significance for substrate processing in the sea. Aquat Microb Ecol 10:223-230

Middelboe M (2000) Bacterial growth rate and marine virushost dynamics. Microb Ecol 40:114-124

Mitchell JG, Fuhrman JA (1989) Centimeter scale vertical heterogeneity in bacteria and chlorophyll a. Mar Ecol Prog Ser 54:141-148

Murray AE, Preston CM, Massana R, Taylor LT, Blakis A, Wu K, DeLong EF (1998) Seasonal and spatial variability of bacterial and archaeal assemblages in the coastal waters near Anvers Island, Antarctica. Appl Environ Microbiol 64:2585-2595

Muyzer G, De Waal EC, Uitterlinden AG (1993) Profiling of complex microbial populations by denaturing gradient gel electrophoresis analysis of polymerase chain reactionamplified genes coding for 16S rRNA. Appl Environ Microbiol 59:695-700

Muyzer G, Brinkhoff T, Nübel U, Santegoeds C, Schäfer H, Wawer C (1998) Denaturing gradient gel electrophoresis (DGGE) in microbial ecology. In: Akkermans ADL, van Elsas JD, De Bruin FJ (eds) Molecular microbial ecology manual Kluwer Academic Publishers, London, p 1-27, section 3.4.4 
Nielsen TG, Richardson K (1989) Food chain structure of the North Sea plankton communities: seasonal variations of the role of the microbial loop. Mar Ecol Prog Ser 56:75-87

Nielsen TG, Kiørboe T, Bjørnsen PK (1990) Effects of a Chrysochromulina polylepis subsurface bloom on the planktonic community. Mar Ecol Prog Ser 62:21-35

Noble RT, Fuhrman JA (1998) Use of SYBR Green I for rapid epifluorescence counts of marine viruses and bacteria. Aquat Microb Ecol 14:113-118

Pinhassi J, Azam F, Hemphälä J, Long RA, Martinez J, Zweifel UL, Hagström Å (1999) Coupling between bacterioplankton species composition, population dynamics, and organic matter degradation. Aquat Microb Ecol 17: $13-26$

Rath J, Schiller C, Herndl GJ (1993) Ectoenzymatic activity and bacterial dynamics along a trophic gradient in the Caribbean Sea. Mar Ecol Prog Ser 102:89-96

Riemann B, Søndergaard M (1984) Measurements of diel rates of bacterial secondary production in aquatic environments. Appl Environ Microbiol 47:632-638

Riemann B, Bjørnsen PK, Newell S, Fallon R (1987) Calculation of cell production of coastal marine bacteria based on measured incorporation of $\left({ }^{3} \mathrm{H}\right)$ thymidine. Limnol Oceanogr 32:471-476

Riemann L, Winding A (2001) Community dynamics of freeliving and particle-associated bacterial assemblages during a freshwater phytoplankton bloom. Microb Ecol 42: 274-285

Riemann L, Steward GF, Fandino LB, Campbell L, Landry MR, Azam F (1999) Bacterial community composition during two consecutive NE Monsoon periods in the Arabian Sea studied by denaturing gradient gel electrophoresis (DGGE) of rRNA genes. Deep-Sea Res II 46:1791-1811

Riemann L, Steward GF, Azam F (2000) Dynamics of bacterial community composition and activity during a mesocosm diatom bloom. Appl Environ Microbiol 66:578-587

Sanders R, Purdie DA (1998) Bacterial response to blooms dominated by diatoms and Emiliania huxleyi in nutrientenriched mesocosms. Estuar Coast Shelf Sci 46(Suppl A): $35-48$

Schäfer H, Benard L, Courties C, Lebaron P and 7 others (2001) Microbial community dynamics in Mediterranean nutrient-enriched seawater mesocosms: changes in the genetic diversity of bacterial populations. FEMS Microbiol Ecol 34:243-253

Schauer M, Massana R, Pedrós-Alió C (2000) Spatial differences in bacterioplankton composition along the Catalan

Editorial responsibility: Gunnar Bratbak,

Bergen, Norway coast (NW Mediterranean) assessed by molecular fingerprinting. FEMS Microbiol Ecol 33:51-59

Seymour JR, Mitchell JG, Pearson L, Waters RL (2000) Heterogeneity in bacterioplankton abundance from 4.5 millimetre resolution sampling. Aquat Microb Ecol 22:143-153

Somerville CC, Knight IT, Straube WL, Colwell RR (1989) Simple, rapid method for direct isolation of nucleic acids from aquatic environments. Appl Environ Microbiol 55: $548-554$

Steward GF (2000) Fingerprinting viral assemblages by pulsed field gel electrophoresis (PFGE). In: Paul JH (ed) Marine microbiology, methods in microbiology. Academic Press, New York, p 85-103

Steward GF, Azam F (2000) Analysis of marine viral assemblages. In: Bell CR, Brylinski M, Johnson-Green P (eds) Microbial biosystems: new frontiers. Proceedings of the 8th International Symposium on Microbial Ecology. Atlantic Canada Society for Microbial Ecology, Halifax, p 159-165

Steward GF, Montiel JL, Azam F (2000) Genome size distributions indicate variability and similarities among viral assemblages from diverse environments. Limnol Oceanogr 45:1697-1706

Tarutani, K, Nagasaki K, Yamaguchi M (2000) Viral impacts on total abundance and clonal composition of the harmful bloom-forming phytoplankton Heterosigma akashiwo. Appl Environ Microbiol 66:4916-4920

Van Hannen EJ, Schwart G, Van Agterveld MP, Gons HJ, Ebert J, Laanbroek HJ (1999) Changes in bacterial and eukaryotic community structure after mass lysis of filamentous cyanobacteria associated with viruses. Appl Environ Microbiol 65:795-801

Weinbauer MG, Peduzzi P (1994) Frequency, size and distribution of bacteriophages in different marine bacterial morphotypes. Mar Ecol Prog Ser 108:11-20

Wolfe GV, Steinke M, Kirst GO (1997) Grazing-activated chemical defense in a unicellular marine alga. Nature 387: 894-897

Wommack KE, Colwell RR (2000) Virioplankton: viruses in aquatic ecosystems. Microbiol Mol Biol Rev 64:69-114

Wommack KE, Ravel J, Hill RT, Chun J, Colwell RR (1999a) Population dynamics of Chesapeake Bay virioplankton: total-community analysis by pulsed-field gel analysis. Appl Environ Microbiol 65:231-240

Wommack KE, Ravel J, Hill RT, Colwell RR (1999b) Hybridization analysis of Chesapeake Bay virioplankton. Appl Environ Microbiol 65:241-250

Submitted: October 18, 2001; Accepted: January 28, 2002 Proofs received from author(s): March 12, 2002 